\title{
Kemik metastazının mekanizmaları
}

\author{
Mechanisms of bone metastasis
}

\author{
Merter Yalçınkaya
}

İstanbul Ortopedi Grubu, Şişli, İstanbul

\begin{abstract}
Kemik metastazı sık rastlanılan, kemiğin mimari yapısını zayıflatarak dayanılmaz ağrı ve patolojik kırıklara neden olabilen, hayatı tehdit eden düzeylerde hiperkalsemi ve spinal kord kompresyonu gibi ciddi klinik sorunlara yol açabilen, kanser olgularının yıkıcı ve masraflı bir komplikasyonudur. Kemik metastazlarının neden olabildiği klinik sorunların önüne geçmek için profilaktik cerrahi girişimlerden, palyatif radyoterapi ve kemoterapi uygulamalarından, belirli algoritmalar eşliğinde yararlanılmaktadır. Tüm bunlara rağmen, bir kanser türü kemiğe metastaz yaptıktan sonra, bu kanser türünün sıklıkla tedavi edilemez bir aşamaya geldiği kabul edilir. Bu görüşün değişebilmesi için, kemik metastazının nasıl geliştiğinin, hücresel düzeyde olan etkileşimlerin neler olduğunun ve kilit rol oynayan moleküler yapıların hangi kaskadlar üzerinden kemik metastazına neden olduğunun çok iyi anlaşılması gerekmektedir. Ancak bu şekilde kemik metastazını engelleyebilecek hedefe yönelik tedavi stratejileri geliştirilebilir ve kanser hastalarının kemik metastazı endişeleri azaltılabilir. Kemik metastazının mekanizmaları, metastaz gelişim teorileri ve olası tedavilere ışık tutabilecek hücresel moleküler etkileşimler özet olarak bu derlemede yer almaktadır.
\end{abstract}

Anahtar sözcülkler: kemik metastazı; osteolitik; osteoblastik; osteoklastogenezis
Bone metastasis is a destructive and costly complication of cancer cases that can cause unbearable pain and pathological fractures by weakening the architectural structure of the bone, and serious clinical problems such as hypercalcemia at life threatening levels and spinal cord compression. Prophylactic surgical procedures, palliative radiotherapy and chemotherapy are used in the management of bone metastases within certain algorithms in order to prevent the clinical problems it may cause. Nevertheless, when a cancer metastasizes to bone, the patient is often considered to be at an incurable stage. In order to change this fate, it is necessary to understand how bone metastasis develops, which interactions at cellular level occur, and which cascades of key molecular structures cause bone metastasis. Only in this way can targeted treatment strategies that can prevent bone metastasis be developed, and bone cancer metastasis concerns of cancer patients may be reduced. In this review, the mechanisms of bone metastasis, theories of metastasis, and cellular molecular interactions that may shed light on possible treatments are summarized.

Key words: bone metastasis; osteolytic; osteoblastic; osteoclastogenesis
K emik metastazı kanser olgularında sık rastlanılan bir komplikasyondur. İlerlemiş meme veya prostat kanseri olgularının yaklaşık \%70'inde ${ }^{[1]}$, akciğer, kolon, mide, mesane, uterus, rektum, tiroid ya da böbrek kanseri olgularının ise yaklaşık \%15-30'unda kemik metastazı gelişir. ${ }^{[2]}$ Kemik metastazının gerçek insidansı bilinmemesine rağmen, Amerika Birleşik Devletleri'nde her yıl 350.000 kişinin kemik metastazı ile birlikte öldüğü tahmin edilmektedir. ${ }^{[3]}$
Bir kanser türü kemiğe metastaz yaptıktan sonra, bu kanser türünün sıklıkla tedavi edilemez bir aşamaya geldiği kabul edilir. Kemik metastazı gelişmiş olan meme kanseri olgularının sadece \%20'sinin kemik metastazının fark edilmesinden sonra beş yıl hayatta kalabildiği bilinmektedir. ${ }^{[4]}$ Normal kemik homeostazını ve remodelling özelliğini bozarak kemiğin mimari yapısını zayıflatan kemik metastazlarının neden olduğu ağrı, patolojik kırık, hayatı tehdit eden düzeylerde hiperkalsemi ve spinal kord kompresyonu

- İletişim adresi: Doç. Dr. Merter Yalçınkaya, İstanbul Ortopedi Grubu, Teşvikiye Mah. Hakkı Yeten Cad. Unimed Center, 19/3, Fulya, Şişli, 34365, İstanbul Tel: 0530 - 2608511 e-posta: merter_99@hotmail.com

- Geliş tarihi: 6 Ağustos 2019 Kabul tarihi: 22 Ekim 2019 
gibi klinik sorunlar ise genellikle hastalar açısından yıkıcı etkilere neden olur. Tüm bu nedenlerden dolayı, kemik metastazı kanserlerin ciddi ve masraflı bir komplikasyonudur.

Kemik metastazları osteolitik ya da osteoblastik karakterde olabilir. Bu sınıflama aslında normal kemik yapım-yıkım dengesinin bozulmasının iki uç örneğini temsil etmektedir. Osteolitik kemik metastazlarının sıklığı osteoblastik karakterde olanlara göre daha fazladır ve bunlar patolojik kırık ve hiperkalsemiye daha fazla neden olur. Tüm kanserler kemikte aynı tip metastaza neden olmaz. Meme ve küçük hücreli dışı akciğer kanserleri sıklıkla osteolitik lezyonlara yol açarken prostat kanserinin kemik metastazları osteoblastik karakterde görünür..$^{[5,6]}$ Zaman zaman ayn hastada osteolitik ve osteoblastik lezyonlar bir arada bulunabilmektedir. Meme kanserlerinin neden olduğu kemik metastazlarının $\% 85$ 'i osteolitik görünümde iken, $\% 15$ 'i osteoblastik ve mikst karakterdedir. ${ }^{[5,7]}$

Metastazlar açısından, kemiğin sıklıkla hedef organ haline gelmiş olmasının bazı nedenleri vardır. Öncelikli neden, kırmızı kemik iliğinin sahip olduğu yüksek kan akımının metastatik bir odağın gelişimi için uygun bir alan oluşturmasıdır. ${ }^{[8]}$ Ayrıca, tümör hücrelerinin ürettiği adhesiv moleküller, bu hücrelerin kemik iliği stromal hücrelerine ve kemik matriksine bağlanmasını sağlar. Bu bağlanma ile, tümör hücreleri anjiyogenik faktörler ve kemik rezorpsiyonuna neden olan faktörleri üretmeye başlar; böylelikle, kemik içerisinde tümöral büyümenin önü açılmış olur. ${ }^{[9]}$ Kemik aynı zamanda, transforming büyüme faktörü- $\beta$ (TGF- $\beta$ ), insülin-benzeri büyüme faktörü (ILGF) I ve II, fibroblast büyüme faktörü (FGF), trombosit kaynaklı büyüme faktörleri (PDGF), kemik morfogenetik proteinler (BMP) ve kalsiyum gibi birçok büyüme faktörüne büyük bir depo görevi de görür. ${ }^{[10]}$ Kemik rezorpsiyonu esnasında salınan ve aktive olan bu faktörler tümör hücrelerinin çoğalması için verimli bir zemin hazırlar.[11] Kemik metastazı mekanizmaları içerisinde "Tohum-toprak hipotezi" olarak adlandırılan bu süreç ilk olarak 1889 yılında Stephan Paget tarafından ortaya konulmuş ${ }^{[12]}$ ve kemik metastazının hayvan modellerindeki bulguları ile de desteklenmiştir. Bu hipotezin özünde "Bir bitki tohum üretmeye başladığında, bu tohumlar her yöne taşınır. Ancak, sadece uygun ortama sahip bir toprağa düşen tohumlar büyüyebilir.” görüşü yatmaktadır. Bu asırık kavram, kanser metastazı anlayışımızın halen temel ilkesidir ve bu ilke, ilerleyen bölümlerde anlatılacak olan kısır döngü kavramındaki kemik ve tümör hücreleri tarafından üretilen moleküllerin araştırılmasındaki mevcut ilerlemeye rehberlik etmektedir.
Kemiğin metastaz açısından "verimli bir toprak" olmasına rağmen, meme, prostat ve akciğer dışındaki organların kanserleri nadiren kemikte metastatik koloni oluşturur. Endometrium kanseri, üretelyal ve baş-boyun tümörlerinin kemik metastazlarına meme veya prostat kanser metastazlarına oranla daha az rastlanır. Buradan yola çıkarak, meme ve prostat karsinomlarının bazı intrinsik özelliklerinin kemik metastazı gelişimine daha kolay yol açtığını söyleyebiliriz. Bu özellikler; 1) primer odaktan ayrılma, çevre yumuşak dokulara yayılma, intravazasyon, ekstravazasyon ve kemik matriks degradasyonu, 2) primer odaktan ayrılma ve metastatik alanda biriktirme için gerekli olan hücre yapışma moleküllerinin (CAM) ekspresyonunun artması veya kaybı, 3 ) vücut içerisinde dolaşıma katılabilmek için göç aktivitesi ve 4) hayatta kalmak için konak immünitesinden kaçma kapasitesinin arttırılması olarak özetlenebilir. ${ }^{[13]} \mathrm{Her}$ ne kadar tüm metastatik hücreler bu özelliklere sahipse de, meme ve prostat kanser hücrelerinin kemiğe olan ilgilerini açıklayabilmek için bazı ilâve özelliklere sahip olmaları gerektiği aşikârdır. Bu nedenle, tümör hücrelerinin spesifik bölgelere metastazı, yalnızca kan akımı ile belirlenen basit bir rastgele işlem değildir; aksine, tümör hücrelerinin spesifik özelliklerine ve metastatik bölge ortamındaki destekleyici faktörlere bağlı olan yönlendirilmiş çok aşamalı bir olaylar dizisidir. Paget'in Tohum-Toprak Hipotezi'nden önceki yıllarda konuya bakış daha farklıydı. Berlin'li anatomist William Waldeyer, 1867'de yayımladığı makalesinde, kanser hücrelerinin bitişik dokulara hareketinin bölgesel yayılmadan sorumlu olduğunu, metastazın ise kanser hücrelerinin uzak organlara kan veya lenf kaynaklı yollar ile transfer olmaları sonucu geliş̧tiğini bildirmiştir. ${ }^{[14]} \mathrm{Bu}$ ifadeler, kanserin "mekanik" yayılması teorisinin formülasyonuna yol açmıştır. ${ }^{[14]}$ Bu teori, 1928 yılında James Ewing tarafindan daha net bir şekilde gündeme getirilmiştir. ${ }^{[15]}$ Ewing, "Neoplastik Hastalıklar” isimli kitabının üçüncü baskısında, metastazların vücut içindeki dağılımını açıklamak için belirli tümör hücrelerinin bazı dokulara olan özel yatkınlıklarını araştırmaya gerek olmadığını belirtmiştir. ${ }^{[14]}$ Ewing'in bu ifadelerinin kitabının dördüncü baskısında yer almıyor olması ise dikkat çekicidir. Bu gelişmeye rağmen, mekanik teori bazı çalışmalar ile ispatlanmaya çalışılmıştır. Batson, vertebral venlerin fonksiyonlarını ve metastazın yayılmasındaki rollerini açıkladığı çalışmasında, akciğer, karaciğer, böbrek, prostat ve tiroid venöz dolaşım yollarının vertebral venöz sistemle bağlantısını göstermiş ve bunun üzerinden vertebral metastazların sıklığını izah etmeye çalışmıştır. ${ }^{[16]}$ Coman ve Delong ise farelerde femoral vene enjekte ettikleri tümör hücrelerinin akciğerde metastatik odak oluşturduğunu, kalbin sol 
atriyumuna enjekte ettiklerinin ise periferik organlarda metastaz oluşturduğunu tespit etmişlerdir. [17]

Ewing'in mekanik ve Paget'in seçici (tohum-toprak) teorilerinin metastatik sürece göreceli katkıları halen tartışılmaktadır. Günümüzde genel olarak, her iki teorinin de sürece katkı verdiği kabul edilmektedir. ${ }^{[14]}$ Metastaz lokasyonlarının yaklaşık \%30-60'ı, tümör hücrelerinin takip ettikleri lenfatik ve/veya hematojen yol nedeniyle tahmin edilebilir durumdadır. ${ }^{[14,18]}$ Kalan kısım için (kemik metastazları da dâhil), tümör ve konak hücreler arasındaki hücresel ve moleküler seviyedeki etkileşimler metastaz olasılığını ve modellerini belirlemektedir.

Kemik metastazı süreci, kanser hücrelerinin primer tümör odağından ayrılarak (kaçarak) dolaşıma katılması, uzak organ adhezyonu/invazyonu ve misafirperver bir ortamda ya da organda çoğalması olarak özetlenebilir.

\section{KANSER HÜCRELERININ KAÇIŞI}

Kanser hücrelerinin kötü huylu olma potansiyeli; hücre bazal membranı ve ekstrasellüler matriks proteinlerini bozma, primer odaktan kaçabilme, çevresindeki dokuları istilâ etme ve vasküler sistemlere girme kabiliyetlerine bağlıdır.

Tümör hücrelerinin primer odaktan kaçışı, tümör hücrelerinin bitişik hücrelerden ayrılması ile başlar. Ardından, tümör hücreleri (tümör tarafından üretilen spesifik anjiyogenetik faktörlerin etkisi ile) vasküler sisteme girer ve genel dolaşıma ulaşır. Tümör hücrelerinin primer odakta vasküler sisteme girmesiyle ilgili mekanizmalar ile tümör hücrelerinin vasküler sistemden çıkıp kemik iliğine geçmesi süreci muhtemelen benzerdir. Bu süreçler arasında; tümör hücrelerinin bazal membrana bağlanması, bazal membranın bozulmasına neden olan proteolitik enzimlerin salgılanması ve daha sonra tümör hücrelerinin bazal membrandan göçü bulunur. ${ }^{[19-21]}$

Tümör hücreleri, bazal membranların yapısını bozmak ve kapiller yataktan hedefledikleri dokunun içerisine geçiş yapmak için bazı proteolitik enzimler salgılar. Bunlardan en önemlisi Tip IV kollajenazdır. ${ }^{[13]}$ Ayrıca, hayvan metastaz kemik modelleri bu süreçte diğer matriks metalloproteinazlarının (MMP'ler) rolünü de desteklemektedir. ${ }^{[22]}$ Prostat kanserine bağlı osteolitik kemik metastazının hayvan deneyi modelinde, MMP-7 eksikliği olan farelerde sitokin reseptör aktivatör nükleer kappa $B$ ligandının (RANKL) hatalı işlenmesi ve azalmış osteoklast aktivasyonuna bağlı olarak daha az osteoliz olduğu gösterilmiştir. ${ }^{[23]}$ MMP ile kemik metastazı arasındaki ilişki konusunda ikna edici çalışmalara rağmen, MMP inhibitörü ilaçların Faz III klinik çaIışmalarının sonuçları aynı ikna edicilik düzeyinde değildir. Bu tutarsızlık, MMP ekspresyonunun tümör hücresinin agresifliği ile ilişkili olduğunu, ancak aralarında nedensel bir bağlantı olmadığını ve tümörogenezin hayvan modelindeki akışının hastalığın insandaki gidişatı ile aynı olmayabileceğini düşündürmektedir.

Kemik metastazı ile trombosit hücreleri arasındaki ilişki de dikkat çekicidir. ${ }^{[13]}$ Trombositler, dolaşımdaki tümör hücrelerinin etrafını çevirerek onları bağışıklık sisteminden gelebilecek bir saldırıya karşı koruyabilir ve bozulmuş vasküler endotele yapışma yeteneklerini arttırabilir. ${ }^{[24]}$ Bir başka hayvan çalışmasında, meme kanseri hücrelerinin trombosit agregasyonunu ve lizofosfatidik asit salınımını uyardığı, bu durumun interlökin(IL)-8 gibi osteolitik faktör üretimini arttırdığı gösterilmiştir. ${ }^{[25]}$ Aynı çalışmada, bir $\alpha$ llb $\beta 3$ antagonisti ve trombosit agregasyon inhibitörü olan integrilinin osteolitik kemik lezyonunu azalttığı gösterilmiştir.

\section{KANSER HÜCRELERININ UZAK ORGAN ADHEZYONU}

Tümör hücrelerinin diğer hücrelere ve ekstrasellüler yapılara yapışmasında E-cadherin, integrin ve laminin gibi hücre adhezyon molekülleri görev alır. Farklı metastaz türlerinde ya da metastazın farklı aşamalarında hücre adhezyon moleküllerinin ekspresyonu artabilir ya da azalabilir. ${ }^{[13]}$ Özellikle integrinlerin kanser hücrelerinin vasküler endotelyal hücrelere, laminin ve fibronektin gibi matriks proteinlerine bağlanmasına aracılık ettiği gösterilmiştir. $\mathrm{Bu}$ süreç, tümör kolonizasyonunda anahtar bir ilk adımdır. ${ }^{[26]} \alpha v \beta 3$ integrinin ekstrasellüler matriks proteinlerinde bulunan bazı özel peptidlere bağlanmasının ${ }^{[27,28]}$ tümör hücrelerinin kemik endosteumuna girmesinde önemli bir faktör olduğu düşünülmektedir; zira, $\alpha v \beta 3$ integrin antagonistlerinin kanser hücrelerinin kemiğe invazyonunu engellediği bir hayvan çalışmasında gösterilmiştir. ${ }^{[29]}$ Kanser hücrelerinin uzak organlara adhezyonunu kolaylaştıran bazı özel ligand-reseptör ilişkileri de vardır. Stromal hücre kaynaklı Faktör 1a (SHKF-1a ya da CXCL12) kemik iliğinde bulunan bir liganddır ${ }^{[30-32]}$ ve bu ligandın meme ve prostat kanser hücresinde yüksek oranda üretilen CXCR4 isimli kemokin reseptörüne ciddi bir affinitesi bulunmaktadır. SHKF-1a/ CXCR4 ilişkisinin engellenmesinin prostat kanseri hücrelerinin kemik iliği endotel hücreleri arasından göç etmesini engellediğ ${ }^{[33]}$ ve metastatik yükü azalttığı in vitro olarak gösterilmiştir. ${ }^{[31]}$ 


\section{KEMIKTE ÇOĞALMA: OSTEOLITIK LEZYON OLUŞUMU}

Düşünüldüğünün aksine, osteolitik metastazlarda kemik yıkımı tümör hücreleri tarafından değil, osteoklastlar tarafindan gerçekleştirilir. ${ }^{[13,34,35]}$ Ancak, osteoklastların aktivasyonundan tümörün türüne göre birçok faktör sorumlu olabilmektedir. En önemli iki faktör, paratiroid hormon ilişkili protein (PTHrP) ve TGF- $\beta$ dır. ${ }^{[13,36]}$

Kemik metastazı olan bir hastada, metastazın geliştiği kemik içerisinde PTHrP üretimi olur. Artmış lokal kemik PTHrP konsantrasyonu RANKL ekspresyonunu arttırırken osteoblastlardan ve stromal hücrelerden osteoprotegerin salınmasını engeller ve böylelikle osteoklast öncülü hücrelerin üzerinde bulunan RANK üzerinden osteoklastogenezis aktive olmuş olur. ${ }^{[37]}$ Aktive olmuş osteoklastlar kemik yıkımına neden olurken, bir yandan da kemik matriksinden TGF- $\beta$ salınmasına yol açar. TGF- $\beta$, kanser hücrelerinin tekrar uyarılmasına neden olur ve böylelikle kısır döngü başlar. Bu nedenlerle, PTHrP ve/veya TGF- $\beta$ 'nın engellenmesi kemik metastazı tedavisinde ideal bir strateji olarak düşünülmektedir. Zira, TGF- $\beta$ reseptör-1 kinaz inhibitörü SD-208'in, bir hayvan çalışmasında osteoliz miktarını azalttığı görülmüştür. ${ }^{[38]}$ Benzer şekilde; TGF- $\beta$ sinyal yolağının inhibitörü olan SMAD-7'nin over-ekspresyonunun melanom metastazı modelinde kemik lezyonlarını azalttığı gözlenmiştir. ${ }^{[39]}$ Meme kanseri hücreleri tarafından üretilen bir transkripsiyon faktörü olan RUNX-2 (ana görevi TGF- $\beta$ 'ya olan yanıtı modüle etmektir) aktivitesinin bloke edilmesinin, tümör büyümesini ve osteolizi azalttığı bir başka hayvan çalışmasında gözlenmiştir. ${ }^{[40]}$ PTHrP monoklonal antikorunun kullanımının ise meme kanseri kemik metastazlarının daha az sayıda ve daha küçük boyutta olması ile sonuçlandığı belirtilmektedir. ${ }^{[41]}$ Yakın zamanda, bir transkripsiyon faktörü olan GLI-2'nin meme kanseri hücrelerinin PTHrP ekspresyonunu düzenlediği, GLI-2 ekspresyonunun azaltılmasının PTHrP downregülasyonuna ve dolayısı ile tümör ilişkili osteolizin azalmasına neden olduğu gösterilmiştir. ${ }^{[42]}$

Osteolize neden olan diğer faktörler ise IL-6, IL-8, IL-11 ve vasküler endotelyal büyüme faktörüdür ve bu faktörler, PTHrP'nin etkilerini şiddetlendirir. ${ }^{[3,43,44]}$ ILGF-I'in ise kemik metastazı proliferasyonunda rolü vardır. ${ }^{[45,46]}$

\section{Meme Kanserindeki Osteolitik Metastazlar: Kısır Döngü}

Meme kanseri hücreleri, doğrudan ya da dolaylı olarak osteoklast üretimini arttıran faktörler üretir. Bunun karşılığında, osteoklastların neden olduğu kemik rezorpsiyonu, tümörün büyümesini arttıran ve kemik yıkımını şiddetlendiren büyüme faktörlerinin kemik matriksinden açığa çıkmasına neden olur. ${ }^{[47]}$ Meme kanseri hücreleri ve kemiğin mikro-ortamı arasındaki bu karşılıklı etkileşim, kemik yıkımını ve tümör yükünü artıran bir kısır döngü ile sonuçlanır.

Kemik, aktif olmayan büyüme faktörlerinden zengin bir kaynaktır. ${ }^{[11]}$ Bu faktörler, rezorpsiyon süreci sırasında aktive olur ve ardından meme kanseri hücrelerinin çoğalmasını uyarır. Osteoklast üretimini uyaran temel faktörün, meme kanseri hücreleri ve birçok solid tümör hücresi tarafından üretilen PTHrP olduğu düşünülmektedir. ${ }^{[13,41,48,49]}$ Peptidin osteoklast üretimini uyararak neden olduğu kemik rezorpsiyonuna TGF- $\beta$ salınımı neden olur. TGF- $\beta$, meme kanseri hücrelerinden PTHrP üretiminin artmasına neden olur. ${ }^{[50]}$ PTHrP ekspresyonuna neden olan bir diğer faktörün, src (özellikle v-src) onkogen ekspresyonundaki artış olduğu düşünülmektedir. ${ }^{[13,51]}$ Sonuç olarak; meme kanserinin kemik metastazında görülen bu kısır döngünün neden olduğu kemik yıkımı lokal kalsiyum seviyesinin artması ile sonuçlanır. Meme kanseri hücreleri tarafindan eksprese edilen kalsiyum-algılama reseptörleri ekstrasellüler kalsiyum konsantrasyonundaki en ufak değişimleri bile algılar ve PTHrP üretimini teşvik eder. ${ }^{[52,53]} \mathrm{Bu}$ etki TGF- $\beta$ tarafindan da arttırılır.

Meme kanseri hücreleri aynı zamanda IL-6, IL-8, IL11 prostaglandin E2, makrofaj koloni stimülan faktör, IL-1 ve tümör nekroz faktör- $\alpha$ (TNF- $\alpha$ ) gibi faktörleri de üretir ya da üretimini uyarır. ${ }^{[49,54,55]}$ Tüm bu faktörlerin osteoklast üretiminin uyarılmasında önemli rolü vardır. Prostaglandin E2, RANKL ekspresyonunu uyarır. Benzer şekilde, hem PTHrP hem de paratiroid hormonu aynı reseptöre (PTHR1) bağlanarak kemik iliği stromal hücrelerinde RANKL ekspresyonunu uyarır. RANKL ise osteoklast üretiminin güçlü bir uyarıcısıdır. Tüm veriler birlikte değerlendirildiğinde, PTHrP meme kanseri ve diğer solid tümörlerin neden olduğu osteolitik kemik yıkımı sürecinin en önemli mediyatörüdür (Şekil 1).

Tanımlanmış moleküler yolakların varlığına rağmen, özellikle meme kanserinin kemiğe metastazı tamamen aydınlatılmış değildir. ${ }^{[56]}$ Güncel çalışmalar kemik iliğine yerleşmiş olan dissemine tümör hücrelerinin (DTH) varlığına odaklanmış durumdadır ve kemikte tespit edilebilen metastatik bir odağın olmadığı hallerde bile kemik iliğinde meme kanserine ait DTH'lerin bulunabildiği gösterilmiştir. ${ }^{[57]}$ Kemik iliğinde DTH varlığının kemik metastazı gelişimi riskini arttırdığı aşikâr ve bunun olumsuz bir prognostik faktör olduğu ifade edilse bile ${ }^{[58,59]}$, DTH'nin tespit edilebildiği hastaların sadece $\% 50$ 'sinde ortalama 10 


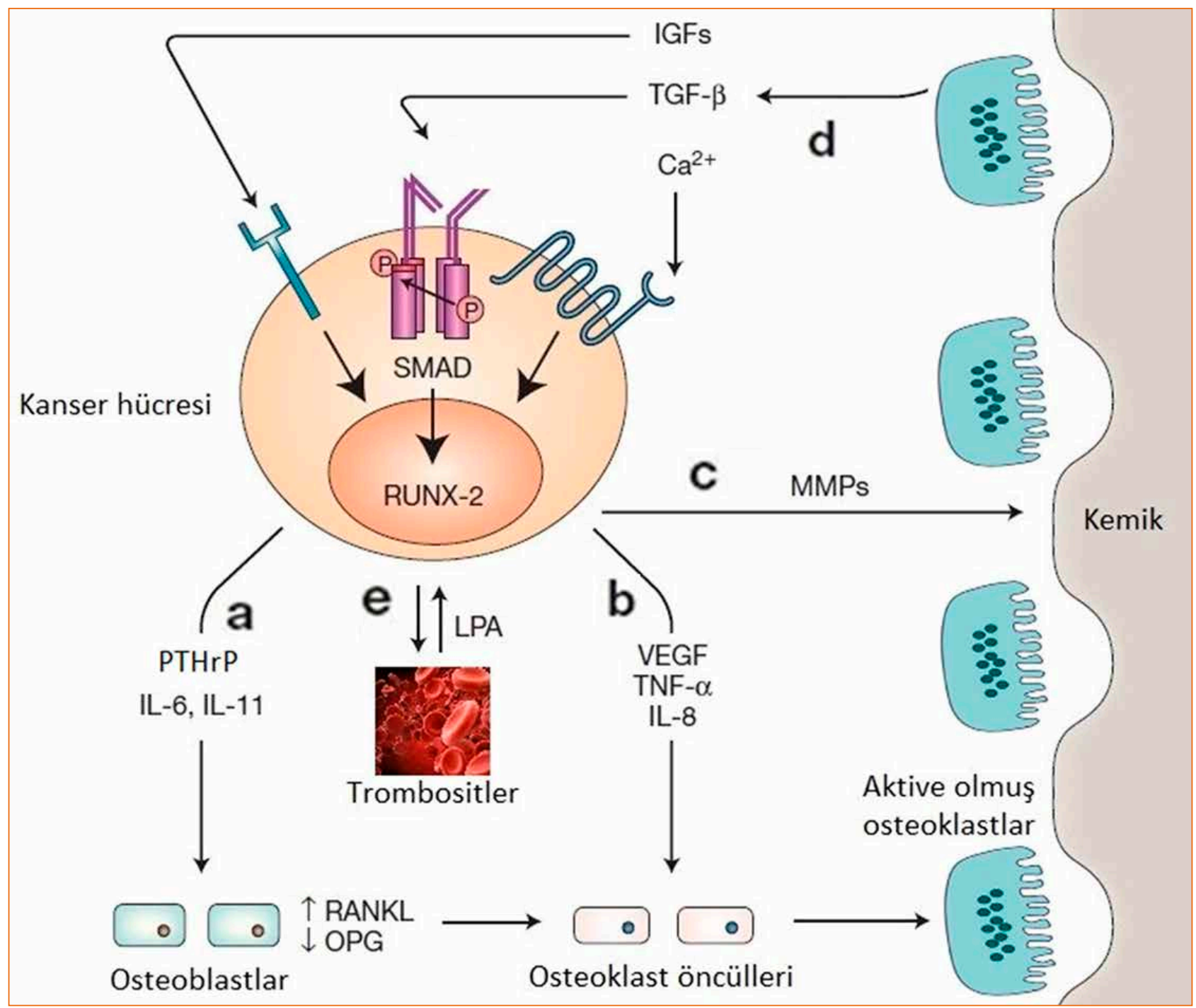

Şekil 1. Meme kanserinin osteolitik metastazında kemik rezorpsiyonu. Metastatik meme kanseri hücreleri kemiği istila eder ve osteoklastogeneze neden olan faktörleri kemik mikro-çevresine salgılar. Normal kemik remodelling'inde ve osteoklastik kemik rezorpsiyonunda yer alan sinyal yolları metastatik meme kanseri hücreleri tarafından kullanılmaya başlanır. Tümör tarafından üretilen PTHrP, IL-6 ve IL-11, osteoblast kökenli RANKL'ı artırırken osteoprotegerin (OPG) aktivitesini azaltır, sonuç olarak osteoklastogenez artar (a). Tümör hücreleri tarafından salgılanan IL-8, TNF-a ve VEGF de osteoklast oluşumunu artırır, ancak bu durum RANK-RANKL etkileşiminden bağımsız olarak gerçekleşir (b). Tümör hücrelerinden üretilen MMP'ler osteoklastların tutunması için kemik yüzeyini hazırlar (C). Kemik rezorpsiyonundaki artış, mineralize kemik matriksinden TGF- $\beta$, ILGF ailesinin üyeleri ve kalsiyum gibi faktörlerin salınımına yol açar (d). TGF- $\beta$, daha fazla osteolitik faktör üretmesi için tümör hücrelerini uyarır (muhtemelen SMAD'ler ve transkripsiyon faktörü RUNX-2 yardımlı sinyalleşme yoluyla). Böylece, osteolitik kemik metastazlarının kısır döngüsü başlar. Ek olarak, ILGF’ler büyüme ve hayatta kalma sinyalleri sağlar ve artmış kalsiyum konsantrasyonu da tümör hücresi aktivasyonuna yol açabilir. Meme kanseri hücreleri, trombosit agregasyonunu ve trombosit kaynaklı LPA salınımını teşvik eder; meme kanseri hücrelerinde LPA reseptörlerinin aktivasyonu proliferasyonu artırır (e).

yıllık bir takip sürecinin sonrasında kemik metastazı geliştiği gösterilmiştir. ${ }^{[60]}$ Kemik metastazı olmaksızın kemik iliğinde DTH saptanan hastaların (bir diğer adıyla minimal rezidüel hastalık durumunda bulunan hastalar) dâhil edildiği bir çalışmada, bisfosfonat tedavisi alan hastaların kemik iliklerinde tedavi sonrasında DHT tespit edilemediği belirtilmiştir. ${ }^{[61]}$ Bisfosfonatların belirgin anti-tümör etkisinin, minimal rezidüel hastalık statüsünde bulunan kişilerde, aşikâr metastazı bulunan hastalara oranla daha selektif olduğu, hastalıksız sağkalım sürelerini ise belirgin uzattığı düşünülmektedir. ${ }^{[56]}$ 


\section{KEMIKTE ÇOĞALMA: OSTEOBLASTIK LEZYON OLUŞUMU}

Osteoblastik metastazların mekanizması ve etkileyen faktörler, netlik kazanmamış durumdadır. ${ }^{[2,13]} \mathrm{Bu}$ faktörler arasında üzerinde en çok durulanı endotelin1'dir. Endotelin-1'in (ET-1), meme kanserinin neden olduğu osteoblastik metastazlarda etkin rol oynadığı düşünülmektedir. ${ }^{[62]} \mathrm{ET}-1$ 'in kemik organ kültürlerinde kemik yapımını ve osteoblast proliferasyonunu uyardığ| ${ }^{[63]}$, prostat kanserinin neden olduğu osteoblastik metastazlarda ise serum ET-1 seviyelerinin yükseldiği belirtilmektedir. ${ }^{[64]}$ Osteoblastik metastazın oluşturulduğu bir hayvan modelinde, selektif endotelin-1A reseptör antagonisti tedavisinin hem osteoblastik metastazları hem de tümör yükünü azalttığı gösterilmiştir. ${ }^{[62]} \mathrm{Bu}$ sonuçlar, tümörün neden olduğu osteoblast uyarıcı aktivitenin engellenmesinin tümör büyümesini ve osteoblast aktivitesini azalttığı, osteoblastik metastazlarda tümörün osteoblast aktivitesini uyardığı, osteoblastlardan salınan büyüme faktörlerinin ise tümör büyümesini arttırdığı; sonuç olarak, bir kısır döngü sürecinin osteoblastik metastatik lezyon oluşumunda da işlediği izlenimini vermektedir.

$\mathrm{ET}-1$, endotelin-A reseptörü üzerinden osteoblastları uyararak patolojik yeni kemik oluşumuna neden olur. ${ }^{[65]}$ ET-1 aynı zamanda WNT ("wingless" ve "int-1" ifadelerinden oluşturulmuş bir kısaltma) antagonisti olan dickkopf homolog 1'in (DKK-1) otokrin üretimini azaltarak WNT sinyal yolağını aktive eder. ${ }^{[6]}$ WNT sinyal yolağı, normal osteoblast diferansiyasyonu ve fonksiyonu üzerinde kilit etkiye sahiptir. DKK-1 osteoblast aktivitesi ile osteoblastik kemik metastazı sürecinin ana düzenleyicisidir; DKK-1 ile osteoblast aktivitesi arasında belirgin bir ters ilişki mevcuttur. DKK-1 düzeyi hem metastatik odakta üretilen hem de prostat kanseri hücrelerinin ürettiği ET-1 ile kontrol edilir.

Osteoblastik kemik metastazı sürecini tetikleyen diğer faktörler üzerindeki çalışmalar devam etmektedir. Endotelin-1 dışında, PDGF[67], ürokinaz ${ }^{[68,69]}$, prostat spesifik antijen $(\mathrm{PSA})^{[70]}$, TGF- $\beta$, $\mathrm{FGF}^{[71,72]}$ ve $\mathrm{BMP}$ 'nin ${ }^{[73]}$ de süreçte aktif rol oynadığı düşünülmektedir.

\section{Prostat Kanserindeki Osteoblastik Metastazlar}

Prostat kanseri hücrelerinin ürokinaz-tip plazminojen aktivatörünü (u-PA) fazla üretmelerinin kemik metastazını arttırdığı gösterilmiştir. ${ }^{[68]}$ Kafa karıştırıcı olan, prostat kanserinin, neredeyse her zaman PTHrP ekspresyonu yapmasına rağmen, neden olduğu metastazların sıklıkla osteoblastik olmasıdır. Bunun nedeni
PSA ile ilgili olabilir. Prostat kanser hücreleri aynı zamanda bir kallikrein serin proteaz ailesi üyesi olan PSA salınımı da yapmaktadır. PSA, PTHrP'yi N-terminal ucunda böler, geri kalan parça klasik PTH/PTHrP kaskadının aktivasyonunu sağlayamaz ve böylelikle tümör uyarımlı kemik rezorpsiyonu gelişmez. ${ }^{[70]}$ Ayrıca, PTHrP bölünmesinden geriye kalan PTHrP-1-23 parçası osteoblastik kemik yapımının güçlü bir uyarıcısıdır. Sonuç olarak; PSA'nın neden olduğu proteoliz PTHrP'yi inaktive etmez ama osteolitik bir süreci osteoblastik bir yöne çevirir.

PSA aynı zamanda kemik metastazı gelişimi esnasında ILGF-I, II ve TGF- $\beta$ gibi osteoblastik büyüme faktörlerinin aktive olmasını da sağlar. ${ }^{[70]}$ ILGF'nin bağlanma proteininden proteolitik bölünmesinin ve latent TGF- $\beta$ 'nın PSA tarafından aktif forma dönüştürülmesinin osteoblast uyarılmasına katkıda bulunuyor olabileceği iddia edilmektedir (Şekil 2). ${ }^{[74,75]}$ Tüm bunların dışında, BMP-7 ekspresyonunun azalmasının prostat epitelinin invaziv ve metastatik davranışını teşvik edebileceğ[i[6], PDGF'nin osteoblastik kemik metastazı gelişimini uyarabildiği ve PDGF'nin baskılandığı durumlarda osteoblastik yanıtı baskılayarak osteosklerotik kemik lezyonlarını azalttığı gösterilmiştir. ${ }^{[67]}$

Prostat kanserinde görülen kemik metastazları ağırlıklı olarak osteoblastiktir ve düzensiz kemik trabeküllerinin sayısı artmış durumda olur. ${ }^{[77]} \mathrm{Her}$ ne kadar osteoklast sayısında artış olduğunu gösteren bir histolojik kanıt olmasa da, prostat kanserinin kemik metastazlarında kemik rezorpsiyon marker düzeylerinde artış olmaktadır ve bu artış kemik metastazının olmadığı prostat kanseri hastalarındaki kemik rezorpsiyon marker düzeylerine göre belirgin olarak daha fazladır. ${ }^{[49,78]} \mathrm{Bu}$ nedenle, prostat kanserinde kemik rezorpsiyon marker'ları kemik metastazının yaygınlığını PSA değerlerine göre daha doğru yansıtan değerlerdir. Güncel çalışmalarda, osteoklastik kemik rezorpsiyonunun engellenmesiyle prostat kanseri hastalarında iskelet sistemi ilişkili rahatsızlıkların azaltılması önerilmektedir. ${ }^{[79]}$ Prostat kanserinin araştırıldığı bir hayvan çalışması ise osteoklastik aktivitenin engellenmesinin osteoblastik metastazı önlemediğini göstermiştir. ${ }^{[80]} \mathrm{O}$ nedenle, kemik yıkımının osteoblastik metastaz gelişiminden önce gelip gelmediği veya artmış kemik oluşumunun bir sonucu olup olmadığı halen tartışmalıdır. Yi ve ark.'nın yaptıkları bir osteoblastik metastaz hayvan modelinde, kemik yıkımının kemik oluşumundan önce geliştiği ve osteoklast aktivasyonunun osteoblastik metastaz gelişiminde önemli bir rolü olduğu gösterilmiştir. ${ }^{[67]}$ 


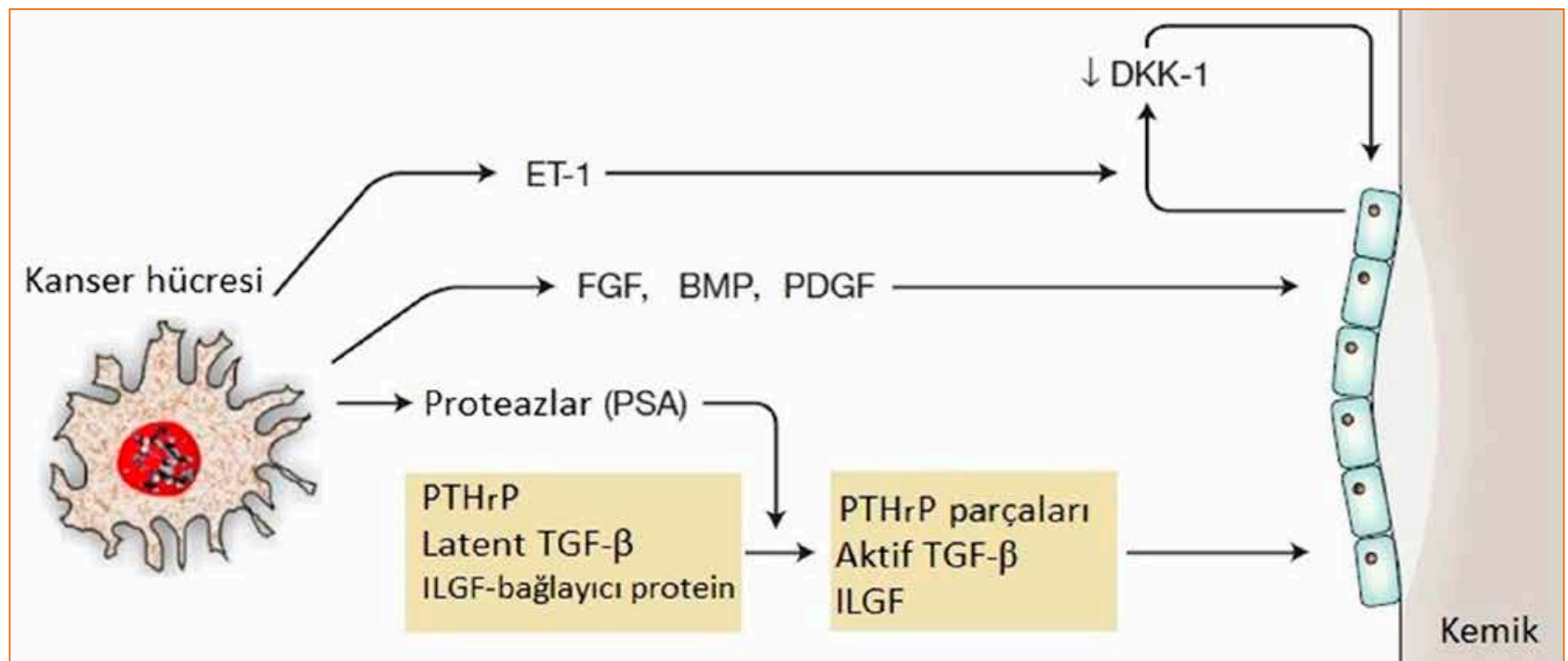

Şekil 2. Prostat kanserinin osteoblastik metastazında kemik oluşumu. Prostat kanseri hücreleri, osteoblast proliferasyonunu ve yeni kemik oluşumunu ET-1, FGF, BMP ve PDGF gibi faktörlerin kemik mikro-çevresine salınması ile uyarır. Tümör tarafından üretilen ET-1, WNT yolu inhibitörü DKK-1'in salgılanmasını azaltarak osteoblast aktivitesini uyarır. Tümör hücresi tarafından üretilen proteazlar (en belirgin olanı prostat spesifik antijendir) PTHrP, TGF- $\beta$ ve ILGF'yi bağlayıcı proteininden ayırır ve osteoblast uyarıcı aktiviteye sahip parçaların oluşmasına neden olur.

\section{KAYNAKLAR}

1. Coleman RE, Rubens RD. The clinical course of bone metastases from breast cancer. Br J Cancer 1987;55(1):61-6. Crossref

2. Roodman GD. Mechanisms of bone metastasis. N Engl J Med 2004;350(16):1655-64. Crossref

3. Mundy GR. Metastasis to bone: causes, consequences and therapeutic opportunities. Nat Rev Cancer 2002;2(8):58493. Crossref

4. Coleman RE. Metastatic bone disease: clinical features, pathophysiology and treatment strategies. Cancer Treat Rev 2001;27(3):165-76. Crossref

5. Käkönen SM, Mundy GR. Mechanisms of osteolytic bone metastases in breast carcinoma. Cancer 2003;97(3 Suppl):834-9. Crossref

6. Charhon SA, Chapuy MC, Delvin EE, Valentin-Opran A, Edouard CM, Meunier PJ. Histomorphometric analysis of sclerotic bone metastases from prostatic carcinoma special reference to osteomalacia. Cancer 1983;51(5):918-24. Crossref

7. Coleman RE, Seaman JJ. The role of zoledronic acid in cancer: clinical studies in the treatment and prevention of bone metastases. Semin Oncol 2001;28(2 Suppl 6):11-6. Crossref

8. Kahn D, Weiner GJ, Ben-Haim S, Ponto LL, Madsen MT, Bushnell DL, Watkins GL, Argenyi EA, Hichwa RD. Positron emission tomographic measurement of bone marrow blood flow to the pelvis and lumbar vertebrae in young normal adults. Blood 1994;83(4):958-63. [Erratum, Blood 1994;84(10):3602.]

9. van der Pluijm G, Sijmons $B$, Vloedgraven $H$, Deckers $M$, Papapoulos S, Löwik C. Monitoring metastatic behavior of human tumor cells in mice with species-specific polymerase chain reaction: elevated expression of angiogenesis and bone resorption stimulators by breast cancer in bone metastases. $J$ Bone Miner Res 2001;16(6):1077-91. Crossref
10. Hauschka PV, Mavrakos AE, lafrati MD, Doleman SE, Klagsbrun M. Growth factors in bone matrix. Isolation of multiple types by affinity chromatography on heparinSepharose. J Biol Chem 1986;261(27):12665-74.

11. Pfeilschifter J, Mundy GR. Modulation of type beta transforming growth factor activity in bone cultures by osteotropic hormones. Proc Natl Acad Sci U S A 1987;84(7):2024-8. Crossref

12. Paget $\mathrm{S}$. The distribution of secondary growths in cancer of the breast. Lancet 1889;133(3421):571-3. Crossref

13. Mundy GR. Mechanisms of bone metastasis. Cancer 1997;80(8 Suppl):1546-56. Crossref

14. Eccles SA. General Mechanisms of Metastasis. In: Jasmin C, Capanna R, Coleman RE, Coia LR, Saillant G, editors. Textbook of Bone Metastasis. West Sussex: John Wiley \& Sons Ltd; 2005. p.3-26.

15. Ewing J. Neoplastik Diseases: A Treatise on Tumors, 3rd Ed. Philadelphia and London: WB Saunders Co Ltd; 1928.

16. Batson $\mathrm{OV}$. The function of the vertebral veins and their role in the spread of metastases. Ann Surg 1940;112(1):138-49. Crossref

17. Coman DR, Delong RP. The role of the vertebral venous system in the metastasis of cancer to the spinal column; experiments with tumor-cell suspensions in rats and rabbits. Cancer 1951;4(3):610-8. Crossref

18. Liotta LA, Kohn E. Cancer invasion and metastases. JAMA 1990;263(8):1123-6.

19. Liotta LA, Tryggvason K, Garbisa S, Hart I, Foltz CM, Shafie S. Metastatic potential correlates with enzymatic degradation of basement membrane collagen. Nature 1980;284(5751):678. Crossref

20. Liotta LA, Mandler R, Murano G, Katz DA, Gordon RK, Chiang PK, Schiffmann E. Tumor cell autocrine motility factor. Proc Natl Acad Sci U S A 1986;83(10):3302-6. Crossref 
21. Liotta LA, Steeg PS. Clues to the function of $\mathrm{Nm} 23$ and Awd proteins in development, signal transduction, and tumor metastasis provided by studies of Dictyostelium discoideum. J Natl Cancer Inst 1990;82(14):1170-2. Crossref

22. Egeblad $M$, Werb $Z$. New functions for the matrix metalloproteinases in cancer progression. Nat Rev Cancer 2002;2(3):161-74. Crossref

23. Lynch CC, Hikosaka A, Acuff HB, Martin MD, Kawai N, Singh RK, Vargo-Gogola TC, Begtrup JL, Peterson TE, Fingleton B, Shirai T, Matrisian LM, Futakuchi M. MMP-7 promotes prostate cancer-induced osteolysis via the solubilization of RANKL. Cancer Cell 2005;7(5):485-96. Crossref

24. Palumbo JS, Talmage KE, Massari JV, La Jeunesse CM, Flick MJ, Kombrinck KW, Jirousková M, Degen JL. Platelets and fibrin(ogen) increase metastatic potential by impeding natural killer cell-mediated elimination of tumor cells. Blood 2005;105(1):178-85. Crossref

25. Boucharaba $A$, Serre $C M$, Grès $S$, Saulnier-Blache JS, Bordet JC, Guglielmi J, Clézardin P, Peyruchaud O. Plateletderived lysophosphatidic acid supports the progression of osteolytic bone metastases in breast cancer. J Clin Invest 2004;114(12):1714-25. Crossref

26. Albelda SM, Buck CA. Integrins and other cell adhesion molecules. FASEB J 1990;4(11):2868-80. Crossref

27. Sung V, Stubbs JT 3rd, Fisher L, Aaron AD, Thompson EW. Bone sialoprotein supports breast cancer cell adhesion proliferation and migration through differential usage of the alpha (v) beta3 and alpha (v) beta5 integrins. J Cell Physiol 1998;176(3):482-94. Crossref

28. Felding-Habermann B, O'Toole TE, Smith JW, Fransvea E, Ruggeri ZM, Ginsberg MH, Hughes PE, Pampori N, Shattil SJ, Saven A, Mueller BM. Integrin activation controls metastasis in human breast cancer. Proc Natl Acad Sci U S A 2001;98(4):1853-8. Crossref

29. Zhao $Y$, Bachelier R, Treilleux I, Pujuguet $P$, Peyruchaud $O$, Baron R, Clément-Lacroix P, Clézardin P. Tumor alphavbeta3 integrin is a therapeutic target for breast cancer bone metastases. Cancer Res 2007;67(12):5821-30. Crossref

30. Müller A, Homey B, Soto H, Ge N, Catron D, Buchanan ME, McClanahan T, Murphy E, Yuan W, Wagner SN, Barrera JL, Mohar A, Verástegui E, Zlotnik A. Involvement of chemokine receptors in breast cancer metastasis. Nature 2001;410(6824):50-6. Crossref

31. Sun YX, Schneider A, Jung Y, Wang J, Dai J, Wang J, Cook K, Osman NI, Koh-Paige AJ, Shim H, Pienta KJ, Keller ET, McCauley LK, Taichman RS. Skeletal localization and neutralization of the SDF-1(CXCL12)/CXCR4 axis blocks prostate cancer metastasis and growth in osseous sites in vivo. J Bone Miner Res 2005;20(2):318-29. Crossref

32. Wang J, Loberg R, Taichman RS. The pivotal role of CXCL12(SDF-1)/CXCR4 axis in bone metastasis. Cancer Metastasis Rev 2006;25(4):573-87. Crossref

33. Taichman RS, Cooper C, Keller ET, Pienta KJ, Taichman NS, McCauley LK. Use of the stromal cell-derived factor-1/CXCR4 pathway in prostate cancer metastasis to bone. Cancer Res 2002;62(6):1832-7.

34. Taube T, Elomaa I, Blomqvist C, Beneton MN, Kanis JA. Histomorphometric evidence for osteoclast-mediated bone resorption in metastatic breast cancer. Bone 1994;15(2):161-6. Crossref

35. Boyde A, Maconnachie E, Reid SA, Delling G, Mundy GR. Scanning electron microscopy in bone pathology: review of methods, potential and applications. Scan Electron Microsc 1986;(Pt 4):1537-54.

36. Yin JJ, Chirgwin JM, Taylor SD, Dallas J, Massague J, Mundy GR, Guise TA. Dominant-negative blockade of the transforming growth factor $\beta$ (TGF $\beta$ ) type II receptor decreases breast cancer-mediated osteolysis. ASBMR 18th Annual Meeting; 1996. S139. https://asbmr.onlinelibrary. wiley.com/doi/epdf/10.1002/jbmr.5650111202
37. Thomas RJ, Guise TA, Yin J, Elliott J, Horwood NJ, Martin TJ, Gillespie MT. Breast cancer cells interact with osteoblasts to support osteoclast formation. Endocrinology 1999;140(10):4451-8. Crossref

38. Mohammad KS, Stebbins EG, Niewolna M, McKenna CR, Walton H, Peng XH, Li G, Murphy A, Chakravarty S, Higgins LS, Wong DH, Guise TA. TGF-beta signaling blockade reduces osteolytic bone metastases and enhances bone mass. Cancer Treat Rev 2006;32(Suppl 3):S29.

39. Javelaud D, Mohammad KS, McKenna CR, Fournier P, Luciani F, Niewolna M, André J, Delmas V,s Larue L, Guise TA, Mauviel A. Stable overexpression of Smad7 in human melanoma cells impairs bone metastasis. Cancer Res 2007;67(5):2317-24. Crossref

40. Javed A, Barnes GL, Pratap J, AntkowiakT, Gerstenfeld LC, van Wijnen AJ, Stein JL, Lian JB, Stein GS. Impaired intranuclear trafficking of Runx2(AML3/CBFA1) transcription factors in breast cancer cells inhibits osteolysis in vivo. Proc Natl Acad Sci U S A 2005;102(5):1454-9. Crossref

41. Guise TA, Yin JJ, Taylor SD, Kumagai Y, Dallas M, Boyce BF, Yoneda T, Mundy GR. Evidence for a causal role of parathyroid hormone-related protein in the pathogenesis of human breast cancer-mediated osteolysis. J Clin Invest 1996;98(7):1544-9. Crossref

42. Sterling JA, Oyajobi BO, Grubbs B, Padalecki SS, Munoz SA, Gupta A, Story B, Zhao M, Mundy GR. The hedgehog signaling molecule Gli2 induces parathyroid hormone-related peptide expression and osteolysis in metastatic human breast cancer cells. Cancer Res 2006;66(15):7548-53. Crossref

43. Käkönen SM, Kang Y, Carreon MR, Niewolna M, Käkönen RS, Chirgwin JM, Massague J, Guise TA. Breast cancer cell lines selected from bone metastases have greater metastatic capacity and express increased vascular endothelial growth factor (VEGF), interleukin$11(\mathrm{IL}-11)$, and parathyroid hormone-related protein (PTHrP). ASBMR 24th Annual Meeting; 2002. S409. https://asbmr. onlinelibrary.wiley.com/doi/epdf/10.1002/jbmr.5650111202

44. de la Mata J, Uy HL, Guise TA, Story B, Boyce BF, Mundy GR, Roodman GD. Interleukin- 6 enhances hypercalcemia and bone resorption mediated by parathyroid hormone-related protein in vivo. J Clin Invest 1995;95(6):2846-52. Crossref

45. Sachdev D, Yee D. The IGF system and breast cancer. Endocr Relat Cancer 2001;8(3):197-209. Crossref

46. Yoneda T, Williams PJ, Hiraga T, Niewolna M, Nishimura R. A bone-seeking clone exhibits different biological properties from the MDA-MB-231 parental human breast cancer cells and a brain-seeking clone in vivo and in vitro. J Bone Miner Res 2001;16(8):1486-95. Crossref

47. Chirgwin JM, Guise TA. Molecular mechanisms of tumorbone interactions in osteolytic metastases. Crit Rev Eukaryot Gene Expr 2000;10(2):159-78. Crossref

48. Shen X, Falzon M. PTH-related protein modulates PC-3 prostate cancer cell adhesion and integrin subunit profile. Mol Cell Endocrinol 2003;199(1-2):165-77. Crossref

49. Guise TA, Mohammad KS, Clines G, Stebbins EG, Wong DH, Higgins LS, Vessella R, Corey E, Padalecki S, Suva L, Chirgwin JM. Basic mechanisms responsible for osteolytic and osteoblastic bone metastases. Clin Cancer Res 2006;12(20 Pt 2):6213s-6s. Crossref

50. Yin JJ, Selander K, Chirgwin JM, Dallas M, Grubbs BG, Wieser R, Massagué J, Mundy GR, Guise TA. TGF-beta signaling blockade inhibits PTHrP secretion by breast cancer cells and bone metastases development. J Clin Invest 1999;103(2):197206. Crossref

51. Li X, Drucker DJ. Parathyroid hormone-related peptide is a downstream target for ras and src activation. J Biol Chem 1994;269(9):6263-6.

52. Buchs N, Manen D, Bonjour JP, Rizzoli R. Calcium stimulates parathyroid hormone-related protein production in Leydig tumor cells through a putative cation-sensing mechanism. Eur J Endocrinol 2000;142(5):500-5. Crossref 
53. Sanders JL, Chattopadhyay N, Kifor O, Yamaguchi T, Butters RR, Brown EM. Extracellular calcium-sensing receptor expression and its potential role in regulating parathyroid hormone-related peptide secretion in human breast cancer cell lines. Endocrinology 2000;141(12):4357-64. Crossref

54. Grano M, Mori G, Minielli V, Cantatore FP, Colucci S, Zallone AZ. Breast cancer cell line MDA-231 stimulates osteoclastogenesis and bone resorption in human osteoclasts. Biochem Biophys Res Commun 2000;270(3):1097-100. Crossref

55. Wani MR, Fuller K, Kim NS, Choi Y, Chambers T. Prostaglandin E2 cooperates with TRANCE in osteoclast induction from hemopoietic precursors: synergistic activation of differentiation, cell spreading, and fusion. Endocrinology 1999;140(4):1927-35. Crossref

56. Cawthorn TR, Amir E, Broom R, Freedman O, Gianfelice D, Barth D, Wang D, Holen I, Done SJ, Clemons M. Mechanisms and pathways of bone metastasis: challenges and pitfalls of performing molecular research on patient samples. Clin Exp Metastasis 2009;26(8):935-43. Crossref

57. Langer I, Guller U, Koechli OR, Berclaz G, Singer G, Schaer G, Fehr MK, Hess T, Oertli D, Bronz L, Schnarwyler $B$, Wight $E$, Uehlinger $U$, Infanger $E$, Burger D, Zuber M; Swiss Multicenter Sentinel Lymph Node Study Group in Breast Cancer. Association of the presence of bone marrow micrometastases with the sentinel lymph node status in 410 early stage breast cancer patients: results of the Swiss Multicenter Study. Ann Surg Oncol 2007;14(6):1896-903. Crossref

58. Braun S, Pantel K. Clinical significance of occult metastatic cells in bone marrow of breast cancer patients. Oncologist 2001;6(2):125-32. Crossref

59. Janni W, Hepp F, Rjosk D, Kentenich C, Strobl B, Schindlbeck C, Hantschmann P, Sommer H, Pantel K, Braun S. The fate and prognostic value of occult metastatic cells in the bone marrow of patients with breast carcinoma between primary treatment and recurrence. Cancer 2001;92(1):46-53. Crossref

60. Braun S, Vogl FD, Naume B, Janni W, Osborne MP, Coombes RC, Schlimok G, Diel IJ, Gerber B, Gebauer G, Pierga JY, Marth C, Oruzio D, Wiedswang G, Solomayer EF, Kundt G, Strobl B, Fehm T, Wong GY, Bliss J, Vincent-Salomon A, Pantel K. A pooled analysis of bone marrow micrometastasis in breast cancer. N Engl J Med 2005;353(8):793-802. Crossref

61. Rack B, Janni W, Schoberth A, Heinrigs $M$, Schindlbeck $C$, Strobl B, Blankenstein T, Sommer H, Friese K. Secondary adjuvant therapy with zoledronate in patients with early breast cancer: is there an effect on persisting isolated tumor cells (ITC) in the bone marrow (BM)? Breast Cancer Res Treat 2004;88(Suppl 1):S228.

62. Guise TA, Yin JJ, Mohammad KS. Role of endothelin-1 in osteoblastic bone metastases. Cancer 2003;97(3 Suppl):779-84. Crossref

63. Kasperk CH, Börcsök I, Schairer HU, Schneider U, Nawroth PP, Niethard FU, Ziegler R. Endothelin-1 is a potent regulator of human bone cell metabolism in vitro. Calcif Tissue Int 1997;60(4):368-74. Crossref

64. Nelson JB, Hedican SP, George DJ, Reddi AH, Piantadosi S, Eisenberger MA, Simons JW. Identification of endothelin-1 in the pathophysiology of metastatic adenocarcinoma of the prostate. Nat Med 1995;1(9):944-9. Crossref

65. Yin JJ, Mohammad KS, Käkönen SM, Harris S, Wu-Wong JR, Wessale JL, Padley RJ, Garrett IR, Chirgwin JM, Guise TA. A causal role for endothelin-1 in the pathogenesis of osteoblastic bone metastases. Proc Natl Acad Sci U S A 2003;100(19):10954-9. Crossref

66. Clines GA, Mohammad KS, Bao Y, Stephens OW, Suva LJ, Shaughnessy JD Jr, Fox JW, Chirgwin JM, Guise TA. Dickkopf homolog 1 mediates endothelin-1-stimulated new bone formation. Mol Endocrinol 2007;21(2):486498. Crossref
67. Yi B, Williams PJ, Niewolna M, Wang Y, Yoneda T. Tumorderived platelet-derived growth factor-BB plays a critical role in osteosclerotic bone metastasis in an animal model of human breast cancer. Cancer Res 2002;62(3):917-23.

68. Achbarou A, Kaiser S, Tremblay G, Ste-Marie LG, Brodt P, Goltzman D, Rabbani SA. Urokinase overproduction results in increased skeletal metastasis by prostate cancer cells in vivo. Cancer Res 1994;54(9):2372-7.

69. Rabbani SA, Desjardins J, Bell AW, Banville D, Mazar A, Henkin J, Goltzman D. An amino-terminal fragment of urokinase isolated from a prostate cancer cell line (PC-3) is mitogenic for osteoclast-like cells. Biochem Biophys Res Commun 1990;173(3):1058-64. Crossref

70. Cramer SD, Chen Z, Peehl DM. Prostate specific antigen cleaves parathyroid hormone-related protein in the PTHlike domain: inactivation of PTHrP-stimulated cAMP accumulation in mouse osteoblasts. J Urol 1996;156(2 Pt 1):526-31. Crossref

71. Matuo Y, Nishi N, Matsui S, Sandberg AA, Isaacs JT, Wada F. Heparin binding affinity of rat prostatic growth factor in normal and cancerous prostate: partial purification and characterization of rat prostatic growth factor in the Dunning tumor. Cancer Res 1987;47(1):188-92.

72. Mansson PE, Adams P, Kan M, McKeehan WL. Heparinbinding growth factor gene expression and receptor characteristics in normal rat prostate and two transplantable rat prostate tumors. Cancer Res 1989;49(9):2485-94.

73. Harris SE, Bonewald LF, Harris MA, Sabatini M, Dallas $\mathrm{S}$, Feng JQ, Ghosh-Choudhury N, Wozney J, Mundy GR. Effects of transforming growth factor beta on bone nodule formation and expression of bone morphogenic protein 2, osteocalcin, osteopontin, alkaline phosphatase, and type I collagen mRNA in long-term cultures of fetal rat calvarial osteoblasts. J Bone Miner Res 1994;9(6):855-63. Crossref

74. Fielder PJ, Rosenfeld RG, Graves HC, Grandbois K, Maack CA, Sawamura S, Ogawa Y, Sommer A, Cohen P. Biochemical analysis of prostate specific antigen-proteolyzed insulin-like growth factor binding protein-3. Growth Regul 1994;4(4):164-72.

75. Killian CS, Corral DA, Kawinski E, Constantine RI. Mitogenic response of osteoblast cells to prostate-specific antigen suggests an activation of latent TGF-beta and a proteolytic modulation of cell adhesion receptors. Biochem Biophys Res Commun 1993;192(2):940-7. Crossref

76. Buijs JT, Rentsch CA, van der Horst $G$, van Overveld PG, Wetterwald A, Schwaninger R, Henriquez NV, Ten Dijke P, Borovecki F, Markwalder R, Thalmann GN, Papapoulos SE, Pelger RC, Vukicevic S, Cecchini MG, Löwik CW, van der Pluijm G. BMP7, a putative regulator of epithelial homeostasis in the human prostate, is a potent inhibitor of prostate cancer bone metastasis in vivo. Am J Pathol 2007;171(3):1047-57. Crossref

77. Roudier MP, Vesselle H, True LD, Higano CS, Ott SM, King $\mathrm{SH}$, Vessella RL. Bone histology at autopsy and matched bone scintigraphy findings in patients with hormone refractory prostate cancer: the effect of bisphosphonate therapy on bone scintigraphy results. Clin Exp Metastasis 2003;20(2):171-80. Crossref

78. Maeda H, Koizumi M, Yoshimura K, Yamauchi T, Kawai T, Ogata E. Correlation between bone metabolic markers and bone scan in prostatic cancer. J Urol 1997;157(2):539-43. Crossref

79. Oades GM, Coxon J, Colston KW. The potential role of bisphosphonates in prostate cancer. Prostate Cancer Prostatic Dis 2002;5(4):264-72. Crossref

80. Lee YP, Schwarz EM, Davies M, Jo M, Gates J, Zhang X, Wu J, Lieberman JR. Use of zoledronate to treat osteoblastic versus osteolytic lesions in a severe-combined-immunodeficient mouse model. Cancer Res 2002;62(19):5564-70. 